\title{
Decision Support Systems Model and Their Effect on The Public Health Promotion
}

\author{
Alif Catur Murti ${ }^{1}$, Ahmad Abdul Chamid ${ }^{2}$ \\ \{alif.catur@umk.ac.id ${ }^{1}$, ahmad.abdul@umk.ac.id ${ }^{2}$ \} \\ Department of Informatic Enginering, Universitas Muria Kudus ${ }^{12}$
}

\begin{abstract}
Public health is one of the government's attention at the moment. One way to measure the level of public health is to look at the behavior of clean and healthy life that the community (PHBS). Health promotion become one of the main program owned by Health Department to create condition of society that aware of the importance of health. Implementation of Decision Support System (DSS) in health promotion is needed to overcome the emerging problems. The results of DSS implementation in health promotion create a sustainable cycle that not only able to see level of society condition but also able to improve health condition of society. Another impact that arises with the increasing level of public health is slowly the level of understanding of each individual who initially did not care about health will turn into aware of the importance of health.
\end{abstract}

Keywords: PHBS, DSS, health promotion, sustainable system concept.

\section{Introduction}

Public health is central to the government's attention at this day. One way to measure the level of public health is to look at the behavior of clean and healthy life that the community (PHBS). PHBS is a set of behaviors / actions practiced on the basis of awareness as a result of learning that makes individuals and communities able to help it (self) in the field of health and active action in realizing public health[1].

Health profile data of Kudus District shows unstable public health level in every year. Data on the number of PHBS in 2012 is $66.4 \%$ of all communities in Kudus District, in 2013 PHBS Kudus Distric fell to $62.9 \%$, and in 2014 rise to $69.4 \%$. The health level is influenced by the Jekulo subdistrict which has low population density with large area [2]-[4].

The health sector of Kudus District is under the auspices of District Health Office, which has the duty and responsibility to provide good health services for the community. Therefore, in carrying out the obligations, the District Health Office of Kudus requires, among others, technical guidelines and reference planning, budgeting, implementation and supervision of activities for 5 years called Strategic Plan (RENSTRA) Health Office of Kudus District 2013 2018 [4].

Health promotion become one of the main program owned by Health Department to create condition of society that aware of the importance of health. Health promotion are conducted in areas where the community still has not received health services due to the individual's own defense and the surrounding environment. The educational factor is undeniably the determinant of the public's understanding of the importance of health. Community empowerment through

ICCSET 2018, October 25-26, Kudus, Indonesia

Copyright (C) 2018 EAI

DOI 10.4108/eai.24-10-2018.2280549 
health promotion conducted by Health Office assisted by clinic must be done continuously to improve public health degree[1].

Each health problem, generally caused by three factors that arise simultaneously, that is the seeds of disease or other disruptors, the environment that allows the development of disease seeds and the existence of human life behavior that does not care about the seeds of disease and the environment. Therefore, the health and illness of a person is determined by the behavior of human life itself. Because the problem of behavior change is closely related to the promotion of health, the role of health promotion is needed in improving the public behavior to be free from health problems[5].

Seeing these conditions the health promotion process has not been effective and targeted. Need a Decision Support System (DSS) that can overcome these problems. DSS is able to see the condition of the area that needs to be done health promotion so that the right target to the community that requires empowerment. Precisely target in providing health promotion can directly increase the level of public health. DSS is expected to be able to prioritize the community that really needs empowerment in the form of health promotion or counseling.

\section{Method}

Research conducted in the form of quantitative and qualitative research, and following is the stages of research conducted:

a. Identification of problems

At this stage found the problem of how to implement decision support system in health promotion.

b. Data collection

The data required in this study are the criteria that will be used to determine the level of public health and weighting assessment criteria comparable with the PHBS technical guidelines. In addition, it is necessary to support data sourced from books, journals, and other literature that have something to do with this research.

c. System Analysis and Design

At this stage the process of system analysis, and the following is an information system framework that can be seen in Figure 1:

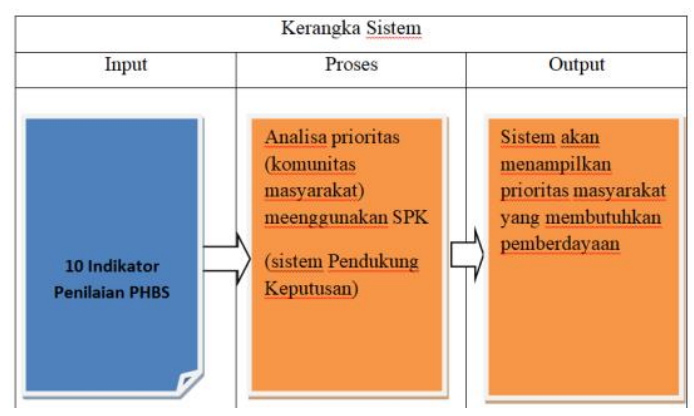

Fig 1. Information system framework. 


\subsection{Decision Support System (DSS)}

Decision support system is an interactive computer-based information system, by processing data with various models to solve unstructured problems so as to provide information that can be used by decision makers in making a decision. In a decision support system, one's intellectual resources are combined with the computer's ability to help improve the quality of decisions taken. Decision-making is a process of selecting an action among several alternatives, so that the desired goal can be achieved, Some methods in Decision Support System such as AHP, SAW, and TOPSIS [6]. For example The TOPSIS method has been widely used as a decisionmaking method, one of which is Xu's research, in his study of TOPSIS method for evaluating NCAA basketball coaches using predetermined criteria. The results showed TOPSIS method was able to evaluate based on positive and negative ideal values[7]. SAW method ever done to overcome the problems of tourism promotion in Kudus district. The main target is how to accommodate the criteria in accordance with the wishes of the tour and the system is able to display recommendations based on these criteria[8]. AHP is a functional hierarchical method that serves to solve complex and unstructured problems. Complex problems will be formed into groups so that it becomes a hierarchical model. Simple Additive Weighting (SAW) method is often also known as weighted summing method. The basic concept of the SAW method is to find the weighted sum of performance ratings on each alternative on all attributes. TOPSIS is a multi-criteria method used to identify solutions from alternative sets based on simultaneous minimization of ideal point spacing and maximize distance from lowest point. TOPSIS can combine the relative weights of important criteria[6]. The main modules of decision support system are database, model base, knowledge base and users. The decision support systems help us to take optimal decisions in complex situations. It is used in education, medicine, business and agriculture etc. Thus it has found its application in every walk of life due to tremendous amount of success achieved in decision making. A lot of research to exploring the norm of decision support system in different fields and huge success it achieved. decision support system has become an integral part of any organization's decision process[9]-[12]. The component of the decision support system is shown in Figure 2.

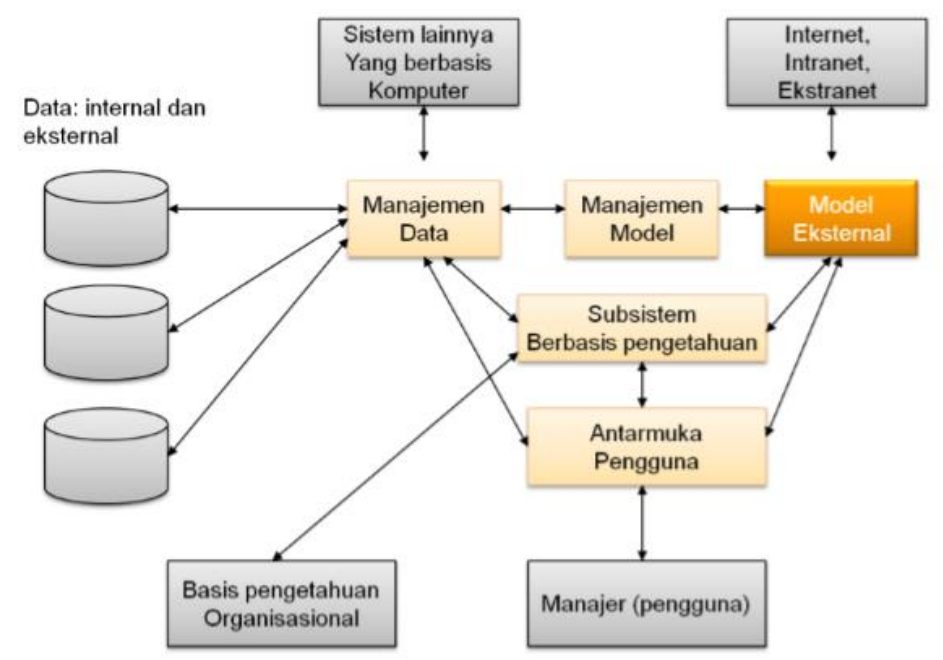


Fig. 2. Component of decision support system.

\subsection{Health Promotion}

The Ministry of Health of the Republic of Indonesia formulates the definition of health promotion as follows: "Efforts to improve people's ability to control health factors through learning from, by, for and with communities, so that they can help themselves, and develop community-based activities, according to local social culture and supported by basic public policy[5].

\section{Result and Discussion}

Implementation of decision support systems in health promotion is rarely done, because the concept of this system is more to prevention efforts. Prevention so that people are not easy to sick, by understanding the importance of healthy living. Most systems today focus more on individuals who have fallen sick to see a medical record, to the verdict of individual illness. Need new approach system to solve that problem like DSS Implementation model on health promotion, that can be seen in the figure 3 .

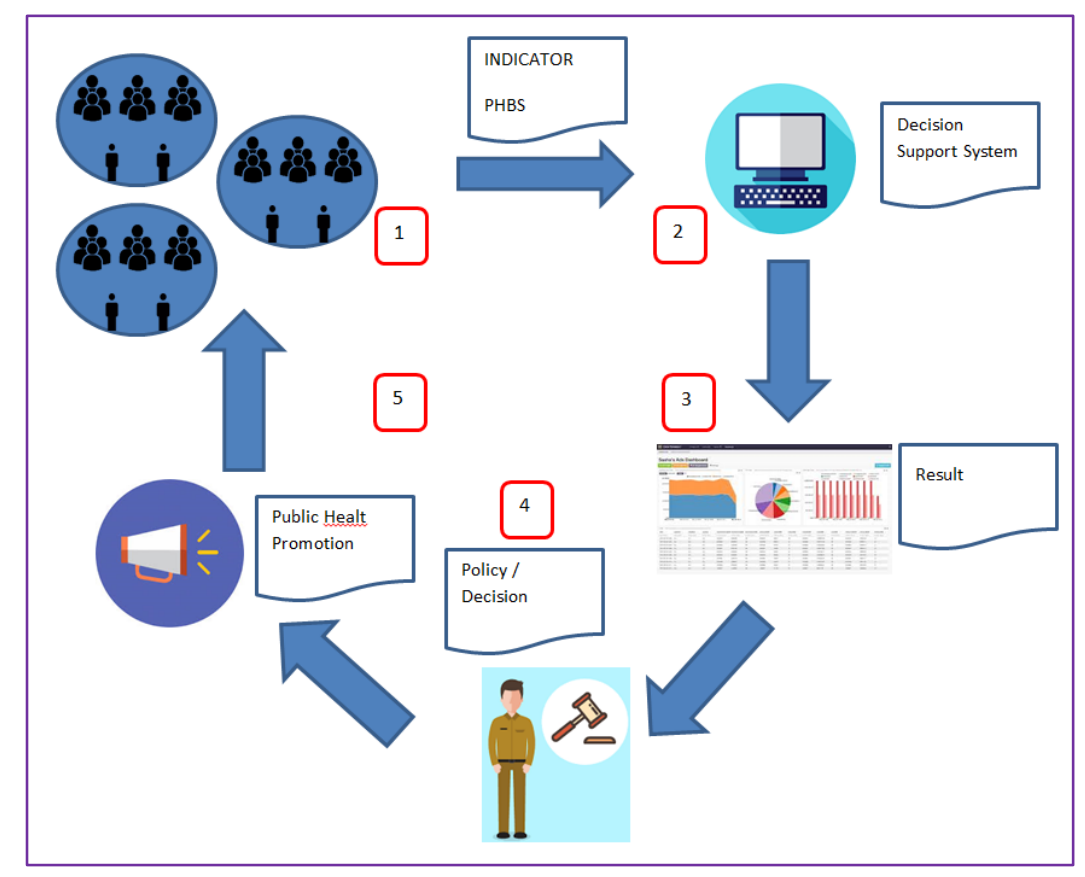

Fig. 3. The sustainable model of Decision Support System Implementation on Public Health Promotion. 
In the drawing concept of the cycle can be seen:

a. Collection of communities that become the object of empowerment. Have different health conditions. Community conditions were measured using the PHBS indicator.

b. The results of indicator measurements were analyzed using DSS. (determining the priority of people eligible for empowerment).

c. The output of the DSS was made into a report that would be easily understood and user-friendly.

d. Reports seen by the leadership / responsible for the consideration of issuing policies related to community empowerment program.

e. The health promotion process is carried out in accordance with the leader's instructions.

The role of DSS is in the data analysis section, the input data in its form will be analyzed using the methods in the decision support system, such as AHP, TOPSIS, SAW etc. the results of data analysis are influenced by the weight values that each criterion has in accordance with the rules and material considerations of the decision maker. The results of data analysis by DSS are numbers that indicate the priority values of all alternatives (community). Very small value differences, such as 0.1 can already be used in determining priority levels.

Equally important is how to change the appearance of data analysis results in the form of numbers into a view that is easily understood by decision makers. Because the ultimate goal of DSS is to be taken into consideration in decision making. Views in the form of charts or graphs can be a solution in making the appearance more user-friendly.

With the formation of the concept of sustainable cycle the level of health can be monitored and for the future can increase. The increase occurs because this cycle can run continuously. The ease in the monitoring process and precisely the empowerment of the community, up to the right target of decision making is the direct effect of the DSS implemented into public health.With the increasing level of public health, slowly the level of understanding of each individual who initially did not care about health will turn into a consciousness of the importance of health.

\section{Conclusion}

Based on the explanation of the results and discussion, the concept of decision support systems can be applied in a health promotion. This concept can be a continuous cycle to improve health conditions in the community. Decision Support System can use various analytical methods such as AHP, SAW or TOPSIS in analyzing criteria appropriate to PHBS. The results of the analysis can be used as a supporter of a decision maker to determine what policy steps will be taken. This step will affect the changing conditions in the community. Precisely the target of community empowerment becomes an important point within the concept of this system. The impact that a rises is the level of change in public health is getting better.

\section{Acknowledgment}

Director of Research and Community Service (DRPM) Kemenristekdikti who has financed this research in the Scheme Research Lecturer Beginners year 2018 implementation, Rector of 
Muria Kudus University, Ka. LPPM Muria Kudus University and Department of Health who supports this research.

\section{References}

[1] Kemenkes, "Promosi Kesehatan di Daerah Bermasalah Kesehatan," Kementrian Kesehat. Republik Indones., p. 118, 2011.

[2] Dinas Kesehatan Kabupaten Kudus, "Profil Kesehatan Kabupaten Kudus Tahun 2012,” 2012.

[3] Dinas Kesehatan Kabupaten Kudus, "Profil Kesehatan Kabupaten Kudus Tahun 2013," 2013.

[4] Dinas Kesehatan Kabupaten Kudus, "Profil Kesehatan Kabupaten Kudus Tahun 2014," no. 15, 2014.

[5] Keputusan Mentri Kesehatan Republik Indonesia, "Pedoman Pelaksanaan Promosi Kesehatan di Puskesmas.Pdf," Pedoman Pelaksanaan Promosi Kesehatan di Puskesmas. pp. 1-36, 2007.

[6] T. turban, efraim, aronson, e, jay, liang, [Efraim_Turban_,Jay_E._Aronson_,Ting_Peng_Liang]_D(BookZa.org).pdf. 2005.

[7] Q. Xu, Y. B. Zhang, J. Zhang, and X. G. Lv, "Improved TOPSIS Model and its Application in the Evaluation of NCAA Basketball Coaches," Mod. Appl. Sci., vol. 9, no. 2, pp. 259-268, 2015.

[8] A. C. Murti and A. A. Chamid, "Sistem Auto Recommendation Objek Wisata Menggunakan Metode SAW," vol. 01, pp. 9-16, 2018.

[9] N. A. I. Anwar, "Significance of Decision Support Systems," vol. 4, no. 4, pp. 2740-2743, 2014.

[10] F. J. Cabrerizo, J. A. Morente-Molinera, I. J. Pérez, J. López-Gijón, and E. Herrera-Viedma, "A decision support system to develop a quality management in academic digital libraries," Inf. Sci. (Ny)., vol. 323, pp. 48-58, 2015.

[11] E. Akçetİn, N. Yurtay, Y. Yurtay, E. Özturk, and A. Kiliç, "Journal of ETA Maritime Science Decision Support Systems: Usage And Applications In Logistics Services DSS in Multimode Transportation," vol. 2, no. 1, pp. 75-80, 2014.

[12] K. P. Tripathi, "Decision Support System Is a Tool for Making Better Decisions in the Organization,” Indian J. Comput. Sci. Eng., vol. 2, no. 1, pp. 112-117, 2011. 